\title{
A Study on Analysing Awareness Towards Demographics of The E- banking Customers
}

\author{
Effulgence \\ Vol. 20, No. 1 \\ January - June 2022 \\ Rukmini Devi Institute of Advanced Studies \\ E-mail : effulgence@rdias.ac.in, Website : www.rdias.ac.in \\ http://effulgence.rdias.ac.in/user/default.aspx \\ https://dx.doi.org/10.33601/effulgence.rdias/v20/i1/2022/01-11
}

\author{
Ms. Shikha Dua $^{1} \nabla$ \\ Dr. Akanksha Upadhyaya ${ }^{2}$
}

\begin{abstract}
The Indian banking industry is the major pillar of growth for the Indian economy. The traditional role of banking has undergone a considerable shift with the introduction of numerous innovative technologies and methods. Traditional banking used to deal with customers in person and was confined to the services that could only be availed by having the physical presence of customers. To provide ease and convenience to the customer, king of the market, the concept of "E-Banking" was introduced two decades ago, allowing customers to avail themselves of banking services anytime, anywhere. "E-Banking" involves the use of information technology in delivering banking services and products. "E-Banking" services and products include ATMs, electronic funds transfers, online banking, mobile banking, point of sale, etc. As per reports of Fidelity National Information Services 2020,68\% of Indian customers are using E-banking services. Therefore, to identify the factors which are contributing towards the awareness level among users of "E-Banking" in North West Delhi; Exploratory Factor Analysis using SPSS 21 has been implemented. Furthermore, hypothesis testing using independent $t$-test and one-way anova has been performed to analyse the relationship between awareness level and characteristics of customers availing of "E-Banking" services. The respondent's characteristics include age, gender, educational level, income level, type of account, frequency of using E-banking services, and association with the bank.
\end{abstract}

Keywords: E-Banking, Internet Banking, Online Banking, Awareness Level, Mobile Banking, Exploratory factor Analysis, Hypothesis Testing, One way Anova, Independent t test.

\section{INTRODUCTION}

$\mathrm{T}$ he computerized quick conveyance of new as well as customary financial items and administrations straightforwardly to target clients through electronic and intuitive correspondence channels is alluded to as "E-banking." E-banking consists of the systems that enable financial institutions such as banks, their clients, people,

1. Assistant professor, RDIAS, shikha.dua29@gmail.com

2. Associate Professor, RDIAS, akanksha0707@gmail.com 
organizations, and ventures to get to accounts, convey business exchanges, and get data on moneyrelated items and administrations through a protected system, including the web. E-banking is the global epitome of E-commerce. Numerous researchers have defined E-Banking in different forms, depicting its connotations and traits. It includes various services such as plastic cards, electronic fund transfers, internet banking, transactions through automated teller machines, and mobile banking. In this volatile and uncertain world, E-banking has evolved as an extension of desktop banking because it utilizes the web relationship to steer banking activities such as bill payments, trading, verification, venture account alterations, credit payments, and many more (Haque, Ismail and Daraz 2009). With the changing environment, most of the things that a human used to do manually are now being automated, and E-banking is one such example. In traditional banking, a customer used to visit the bank branch to perform banking transactions like transfers of amounts from one bank to another, updating of passbooks, account statements, etc. Unlike traditional banking, Ebanking provides convenience to the user by processing their request anytime without being physically present at the bank. The service has now become a "need to have" rather than a "nice to have" e-service. Banks make use of the internet and various other applications to deliver value-added products and services. Technology volatility has made Ebanking popular among its customers. The use of computers and access to the internet is motivating the banks to use the internet as a medium to receive specifications, provide better customer service, and increase their market share. The current study focuses on analysing the awareness level of Ebanking among consumers of banking services.

\section{REVIEW OF LITERATURE}

Our trust in the conventional strategy for banking still stays high; despite the major advantages that Ebanking offers us, people are sceptical about using web-based banking. Payments made via E-banking don't incur any additional charges. However, if done via offline mode, banks usually charge administration or maintenance charges. With the help of E-banking, details about the account can be checked at anytime and anywhere. There are various points of interest for web-based banking as these services are available anytime, anywhere with the least cost in comparison to offline banking services.

Table 1 :

\begin{tabular}{|c|c|c|c|}
\hline S.No. & Author/Year & Findings & Factors Considered \\
\hline 1 & $\begin{array}{l}\text { Yuni Nustini \& } \\
\text { Nurul Fadhillah } \\
\text { (2020) }\end{array}$ & $\begin{array}{l}\text { The research studied the impact of } \\
\text { factors on the usage of E-Banking } \\
\text { services among Moslem students in } \\
\text { Indonesia with the help of "Multiple } \\
\text { Regression Analysis". It was advised } \\
\text { that parents should have control over } \\
\text { the children's money. Faculties or } \\
\text { teachers must focus on the financial } \\
\text { literacy of students. }\end{array}$ & $\begin{array}{l}\text { Service quality, trust, social } \\
\text { influence, Completes of the } \\
\text { Features }\end{array}$ \\
\hline 2 & $\begin{array}{l}\text { Teresa Garín-Munoz' } \\
\text { Rafael Lopez, } \\
\text { Teodosio Perez- } \\
\text { Amaral, Inigo } \\
\text { Herguera, Angel } \\
\text { Valarezo (2019) }\end{array}$ & $\begin{array}{l}\text { The research focused on the factors } \\
\text { that affect decision-making related to } \\
\text { the adoption of "E-commerce," "E- } \\
\text { banking" and "E-government" by } \\
\text { citizens of Spain. As per the results } \\
\text { calculated, income, gender, } \\
\text { education, age, computer skills, and } \\
\text { Internet skills are statistically }\end{array}$ & $\begin{array}{l}\text { E-Commerce, E-Banking \& E- } \\
\text { Government, Age, Gender, } \\
\text { Computer Skills }\end{array}$ \\
\hline
\end{tabular}




\begin{tabular}{|c|c|c|c|}
\hline & & $\begin{array}{l}\text { significant for E-Commerce and E- } \\
\text { Banking but insignificant for E- } \\
\text { Government. Citizens need to boost } \\
\text { their digital skills, and a plan should } \\
\text { be made to increase the digital } \\
\text { literacy of students. }\end{array}$ & \\
\hline 3 & Vishal Kumar (2018) & $\begin{array}{l}\text { The author studied customer } \\
\text { awareness, including demographic } \\
\text { variables, and concluded that E- } \\
\text { banking services are mostly availed } \\
\text { by service class individuals. The low- } \\
\text { income group was not very aware of } \\
\text { the additional services being } \\
\text { provided by the banks. }\end{array}$ & $\begin{array}{l}\text { Demographic variables, Public } \\
\mathrm{n} \text { private Banks, Value Added } \\
\text { Services like Internet Banking } \\
\text { Bancassurance, Tax e- } \\
\text { Payments, ATMs, Plastic } \\
\text { Cards }\end{array}$ \\
\hline 4 & $\begin{array}{l}\text { C Anithamary, M } \\
\text { Harini (2017) }\end{array}$ & $\begin{array}{l}\text { The author brought to light that } \\
\text { customers banking knowing E- } \\
\text { banking are cautious about using the } \\
\text { services of E-banking because of a } \\
\text { lack of sufficient knowledge and } \\
\text { awareness. They know that banks } \\
\text { should focus on providing sufficient } \\
\text { knowledge to customers in the } \\
\text { context of the usage of E-banking } \\
\text { facilities. }\end{array}$ & $\begin{array}{l}\text { Smart Phones, Internet usage, } \\
\text { annual income, and } \\
\text { knowledge about banking } \\
\text { services. }\end{array}$ \\
\hline 5 & $\begin{array}{l}\text { Mrs. T. Amsaveni1 } \\
\text { and Dr. M. } \\
\text { Kanagarathinam } \\
\text { (2017) }\end{array}$ & $\begin{array}{l}\text { This research focused on awareness } \\
\text { of E-banking services provided by } \\
\text { various public banks. The authors } \\
\text { suggested that training programs are } \\
\text { required for both employees and } \\
\text { customers to keep e-banking services } \\
\text { available to large strata of people. }\end{array}$ & 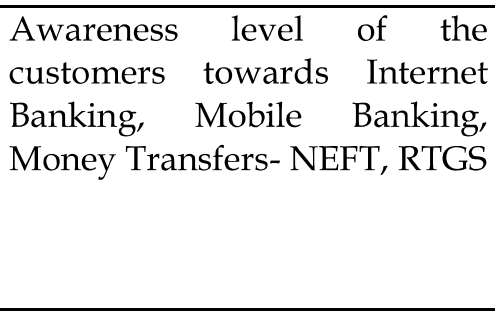 \\
\hline 6 & Das Amutha (2016) & $\begin{array}{l}\text { The research concluded that most of } \\
\text { the customers are availing } \\
\text { themselves of banking services. } \\
\text { Customers should be made aware of } \\
\text { the different E-banking services } \\
\text { offered by the banks. Bank officials } \\
\text { need to have cordial relations with } \\
\text { existing customers and make efforts } \\
\text { to build new customers as well. }\end{array}$ & $\begin{array}{l}\text { Customer Preference, } \\
\text { Motivating Factors, Future } \\
\text { Expectations, Service Quality } \\
\text { Factors }\end{array}$ \\
\hline 7 & $\begin{array}{l}\text { Komal Kaur, Nabin } \\
\text { Subedi, Kajal } \\
\text { Chaudhary, } \\
\text { Shraddha } \\
\text { Parajuli(2016) }\end{array}$ & $\begin{array}{l}\text { The findings show that clients were } \\
\text { aware of the terminologies related to } \\
\text { "E-Banking" but were not very aware } \\
\text { of the processes under E-Banking } \\
\text { services. Internet shopping, } \\
\text { MasterCard, cash exchange, and so } \\
\text { forth were the most popular E- } \\
\text { banking services among the clients. } \\
\text { The driving banks giving E-banking } \\
\text { services to their clients were SBI, } \\
\text { ICICI, and HDFC. }\end{array}$ & $\begin{array}{l}\text { Awareness of respondents } \\
\text { regarding E-banking, services } \\
\text { provided through "E- } \\
\text { banking", Frequency of usage } \\
\text { "E-banking services", Barriers } \\
\text { faced while using "E- } \\
\text { banking", }\end{array}$ \\
\hline
\end{tabular}




\begin{tabular}{|c|c|c|c|}
\hline 8 & $\begin{array}{l}\text { R. Nagaraj, Dr. P. } \\
\text { Jegatheeswari (2016) }\end{array}$ & $\begin{array}{l}\text { As per the study conducted and } \\
\text { responses received, respondents } \\
\text { knew about E-banking. Out of the } \\
\text { choices given, E-banking is the most } \\
\text { popular, followed by ATM, Internet } \\
\text { banking, and mobile banking. The } \\
\text { major advantage of banking services } \\
\text { is time-saving. According to them, if } \\
\text { these services are properly used, our } \\
\text { country will become a superpower in } \\
\text { the year } 2020 \text {. }\end{array}$ & $\begin{array}{l}\text { Reason for Choosing the E- } \\
\text { banking, Use of E-banking, } \\
\text { Problems of ATM with } \\
\text { mentioned the high loading of } \\
\text { variables }\end{array}$ \\
\hline 9 & $\begin{array}{l}\text { Mrs. M. Esther } \\
\text { Krupa, Dr. R. } \\
\text { Rajasekaran (2015) }\end{array}$ & $\begin{array}{l}\text { Due to increasing competition and } \\
\text { the advent of technology from } \\
\text { abroad, the banking sector in India is } \\
\text { undergoing major changes. } \\
\text { Customers are looking for quality } \\
\text { services to satisfy themselves. } \\
\text { This investigation demonstrates that } \\
\text { the statistic states of the clients } \\
\text { assume a significant job in expanding } \\
\text { the level of awareness about E- } \\
\text { Banking Services in Coimbatore city. }\end{array}$ & $\begin{array}{l}\text { Personal Factor vs Awareness } \\
\text { level of E-banking services }\end{array}$ \\
\hline 10 & $\begin{array}{l}\text { R. Elavarasi, } \\
\text { Dr.S.T.Surulivel } \\
(2014)\end{array}$ & $\begin{array}{l}\text { The study aimed to find out the most } \\
\text { preferred value-added service of the } \\
\text { largest bank in India, the State Bank } \\
\text { of India. Analysis shows that age, } \\
\text { income level, occupation of the } \\
\text { customer, and educational } \\
\text { qualification are significant factors } \\
\text { for availing the E-banking services. }\end{array}$ & $\begin{array}{l}\text { Ease \& Convenience in using } \\
\text { Banking Websites, Most } \\
\text { Preferred E-Banking Services } \\
\text { of SBI, Customer Satisfaction } \\
\text { Level in Internet Banking } \\
\text { Website. }\end{array}$ \\
\hline 11 & $\begin{array}{l}\text { Imola Driga and } \\
\text { Claudia Isac (2014) }\end{array}$ & $\begin{array}{l}\text { The research work revealed that } \\
\text { respondents chose Internet Banking } \\
\text { as the most preferred E-banking } \\
\text { service, which is used widely for } \\
\text { online transactions and bill } \\
\text { payments. Mobile channels are } \\
\text { gaining undeniable importance due } \\
\text { to the rise in various applications } \\
\text { that allow users to do mobile } \\
\text { banking. }\end{array}$ & $\begin{array}{l}\text { Preferred banking method, } \\
\text { benefits of E-banking }\end{array}$ \\
\hline 12 & $\begin{array}{l}\text { Jyoti Raj Khatri and } \\
\text { Kshitij Upadhyaya } \\
\text { Dhungel (2013) }\end{array}$ & $\begin{array}{l}\text { The study reveals that male members } \\
\text { are more aware of Internet banking } \\
\text { as compared to female members. } \\
\text { Among the respondents who had } \\
\text { heard about internet banking, their } \\
\text { main sources of information were } \\
\text { media (radio, newspapers, TV) and } \\
\text { the bank itself. Around } 60 \% \text { of them } \\
\text { knew about the internet banking } \\
\text { service provided by their bank. }\end{array}$ & $\begin{array}{l}\text { Awareness level of } \\
\text { respondents, medium of } \\
\text { awareness, Level of usage, } \\
\text { reasons for not availing of "E- } \\
\text { banking" services }\end{array}$ \\
\hline
\end{tabular}




\begin{tabular}{|c|c|c|c|}
\hline 13 & Al-Smadi (2012) & $\begin{array}{l}\text { The research focused on exploring } \\
\text { the factors that affect customers' } \\
\text { usage of E-banking services in } \\
\text { Jordan. One of the factors, namely } \\
\text { "perceived risk," has a significant } \\
\text { effect on customers' attitudes, which } \\
\text { leads to their decision to avail } \\
\text { themselves of the "E-banking" } \\
\text { services. Banks should make E- } \\
\text { banking services more customer- } \\
\text { friendly. Banks should be completely } \\
\text { operational in all domains to provide } \\
\text { the best customer support to users of } \\
\text { banking services. }\end{array}$ & $\begin{array}{l}\text { Most commonly used E- } \\
\text { banking services, Awareness } \\
\text { level, the attitude of } \\
\text { customers, the risk associated } \\
\text { with E-banking }\end{array}$ \\
\hline 14 & S.K.Dutta (2010) & $\begin{array}{l}\text { As per the examination, numerous } \\
\text { components lead to the } \\
\text { acknowledgement of E-banking } \\
\text { administrations among Indian } \\
\text { clients, like security and protection, } \\
\text { trust, ingenuity, recognition, and } \\
\text { mindfulness level. The banks' } \\
\text { administrators, for the most part, } \\
\text { section the market based on age } \\
\text { gathering and then take their } \\
\text { sentiments to furnish them with the } \\
\text { required direction in regards to the } \\
\text { utilization of E-banking. }\end{array}$ & $\begin{array}{l}\text { Awareness level, Innovation, } \\
\text { trust Security \& privacy, } \\
\text { familiarity, }\end{array}$ \\
\hline
\end{tabular}

\section{OBJECTIVES OF STUDY}

- To explore the factors contributing to awareness level of customer towards E Banking services.

- To validate the relationship of awareness level with respondent's characteristics availing $\mathrm{E}$ Banking services.

\section{RESEARCH METHODOLOGY}

A research design is a working pattern of the project that suggests the collection of data, tools to be used, and analysis of the data collected. Primary data was collected through the survey method using Google forms. The structured online questionnaire was comprised of two sections, where the first section dealt with demographic characteristics of respondents, namely age, gender, educational level, income level, type of account, frequency of using Ebanking services, and association with the bank. The questions under the first section were designed as multiple-choice questions. The second section included questions related to the awareness level of the banking services being availed by the respondents. The awareness level questions were based on the variables identified from past studies under the heading "Review of the literature." The questions were designed on a five-point Likert scale, varying from strongly disagree to strongly agree. The "convenience sampling" technique was adopted for collecting responses. The tool used for the data collection to obtain the customer's response was the questionnaire through Google forms and sent to them. For the analysis of the study, IBM SPSS 21 was used. The questionnaire was sent to around 330 people, of whom 249 accurate responses were extracted, making for an approx. $75 \%$ response rate. Data cleaning has been done, 81 responses were removed from the response sheet. To avoid sample bias, Roscoe (1975) proposed that the response rate should be more than $10 \%$. In another study by Sekaran (2003), it was proposed to have more than a 
$30 \%$ response rate for analysis. Table 2 shows the demographic details of respondents.

\section{DATA ANALYSIS AND INTERPRETATION}

Table 2 : Demographics

\begin{tabular}{|c|c|c|}
\hline S. No. & Respondent's Characteristics & Percentage (\%) \\
\hline \multirow[t]{3}{*}{ I } & Gender & \\
\hline & Male & $44.7 \%$ \\
\hline & Female & $55.3 \%$ \\
\hline \multirow[t]{4}{*}{ II } & Age Group & \\
\hline & Up to 25 years & $49.3 \%$ \\
\hline & $26-50$ & $39.5 \%$ \\
\hline & 50 and above & $11.2 \%$ \\
\hline \multirow[t]{5}{*}{ III } & Education Level & \\
\hline & Undergraduate & $31.6 \%$ \\
\hline & Graduate & $24.3 \%$ \\
\hline & Postgraduate & $36.8 \%$ \\
\hline & Others & $7.2 \%$ \\
\hline \multirow[t]{4}{*}{ IV } & Income (in INR) & \\
\hline & $<1 \mathrm{Lac}$ & $36.9 \%$ \\
\hline & 1 Lac- 3 Lac & $30.8 \%$ \\
\hline & $>3 \mathrm{Lac}$ & $32.3 \%$ \\
\hline \multirow[t]{4}{*}{$\mathbf{V}$} & Type of Account & \\
\hline & Saving Account & $77.6 \%$ \\
\hline & Current Account & $17.8 \%$ \\
\hline & NRI Account & $4.6 \%$ \\
\hline \multirow[t]{5}{*}{ VI } & $\begin{array}{l}\text { How long have you been } \\
\text { associated with your bank? }\end{array}$ & \\
\hline & 0 - 1 year & $15.1 \%$ \\
\hline & $1-5$ years & $40.1 \%$ \\
\hline & $6-10$ years & $23.7 \%$ \\
\hline & More than 10 years & $21.1 \%$ \\
\hline
\end{tabular}

\section{Measuring Sample Adequacy}

To measure the adequacy of the sample "KMO and Bartlett's test" was used. The "KMO" value must be greater than. 50 and the p-value must be less than. 05 for Bartlett's test (Kaiser and Rice, 1974). To verify the aptness of factor analysis "KMO and Bartlett's test" was also used. The variance proportion of the variables is shown by $\mathrm{KMO}$ which yields the distinct factors and reliable factors and the presence of 
correlation among the variables is defined by Bartlett's test; it is therefore measured for the p-value less than .005 (Kaiser and Rice, 1974; Hair et.al. 2010). Table 1.1 shows the items that are reliable to continue for factor extraction.

Table 1.1: KMO and Bartlett's Test

\begin{tabular}{|l|l|r|}
\hline \multicolumn{2}{|c|}{ KMO and Bartlett's Test } \\
\hline Kaiser-Meyer-Olkin Measure of Sampling Adequacy. & .900 \\
\hline Bartlett's Test of Sphericity & Chi-Square Value (Approx.) & 883.933 \\
\cline { 2 - 3 } & P Value & .000 \\
\hline
\end{tabular}

\section{Total variance explained}

Table 1.2 shows that a total of 2 factors can be extracted during an exploratory study whose Eigenvalues are greater than 1 while the other factors with Eigenvalue less than 1 have not been considered.

Table 1.2: Total variance explained and Eigenvalue greater than 1

\begin{tabular}{|c|c|c|c|c|c|c|c|c|c|}
\hline \multicolumn{10}{|c|}{ Total Variance Explained } \\
\hline \multirow[t]{2}{*}{ Factor } & \multicolumn{3}{|c|}{ Eigenvalues } & \multicolumn{3}{|c|}{ Sums of Squared } & \multicolumn{3}{|c|}{$\begin{array}{c}\text { Rotation Sums of Squared } \\
\text { Loadings }\end{array}$} \\
\hline & Total & $\begin{array}{c}\% \text { of } \\
\text { Variance }\end{array}$ & $\begin{array}{l}\text { Cumul } \\
\text { ative \% }\end{array}$ & Total & $\begin{array}{c}\% \text { of } \\
\text { Variance }\end{array}$ & $\begin{array}{c}\text { Cumu } \\
\text { lative } \\
\%\end{array}$ & Total & $\begin{array}{c}\% \text { of } \\
\text { Variance }\end{array}$ & $\begin{array}{l}\text { Cumul } \\
\text { ative } \%\end{array}$ \\
\hline 1 & 5.609 & 56.089 & 56.089 & 5.609 & 56.089 & 56.089 & 3.779 & 37.795 & 37.795 \\
\hline 2 & 1.245 & 12.449 & 68.539 & 1.245 & 12.449 & 68.539 & 3.074 & 30.744 & 68.539 \\
\hline
\end{tabular}

\section{Principal Component Analysis}

For extraction of factors, the "Principal component analyses" and "Varimax with Kaiser Normalization rotation" methods have been duly used. A rotated component matrix was used to identify those variables which were combined to form a factor. All the statements showing a value greater than .5 are contributing to making a factor. The convergence of items into a factor has highlighted 2 factors. These factors were extracted and named. The factors were Security mechanism \& banking updates (SMBU) and ease \& quality of work-life (EQWL). The rotated component matrix shows the best fitting of items to form a factor. All the statements showing a value greater than .5 hence these items are contributing to making a factor. As per the convergence of items into a factor 2 factors were extracted and named. These factors were Security mechanism \& banking updates (SMBU) and ease \& quality of work-life (EQWL). 
Table 3 : - Rotated Component Matrix a

\begin{tabular}{|l|c|c|}
\hline \multicolumn{2}{|c|}{ Rotated Component Matrix a } \\
\cline { 2 - 2 } & \multicolumn{2}{|c|}{ Component } \\
\cline { 2 - 2 } & SMBU & \multirow{2}{*}{ EQWL } \\
\hline updates about security & .834 & \multirow{2}{*}{} \\
\hline security measures & .817 & \\
\hline data privacy & .803 & .823 \\
\hline transaction process & .789 & .782 \\
\hline periodic updates & .732 & .758 \\
\hline time savy & & .721 \\
\hline improved working & & .554 \\
\hline Learning use of e-banking & & \\
\hline flexible services & & \\
\hline use and availing services & & \\
& & \\
\end{tabular}

\section{Hypothesis testing:}

Following hypothesis are created to profile the demographics based on the factors extracted through exploratory factor analysis.

H1: "There is no significant difference between Awareness level and gender"

H2: "There is no significant difference between Awareness level and different age groups"

H3: "There is no significant difference between Awareness level and Education level"

H4: "There is no significant difference between Awareness level and Income"

H5: "There is no significant difference between Awareness level and type of account"

H6: "There is no significant difference between Awareness level and association with bank"

H7: "There is no significant difference between Awareness level and frequency of using E-banking services".

\section{Awareness level and gender}

H1: "There is no significant difference between Awareness level and gender"

\begin{tabular}{|c|c|c|c|c|c|c|c|c|c|}
\hline & \multicolumn{2}{|c|}{$\begin{array}{l}\text { Levene's } \\
\text { Test for } \\
\text { Equality of } \\
\text { Variances }\end{array}$} & \multirow{3}{*}{$t$} & \multirow{3}{*}{$\begin{array}{l}\text { Sig. (2- } \\
\text { tailed) }\end{array}$} & \multirow{3}{*}{$\begin{array}{l}\text { Mean } \\
\text { Differ } \\
\text { ence }\end{array}$} & \multirow{3}{*}{$\begin{array}{l}\text { Std. Error } \\
\text { Difference }\end{array}$} & & \\
\hline & & \multirow[t]{2}{*}{$\mathrm{F}$} & \multirow[t]{2}{*}{ Sig. } & & & & & \multicolumn{2}{|c|}{$\begin{array}{c}95 \% \text { Confidence } \\
\text { Interval of the } \\
\text { Difference }\end{array}$} \\
\hline & & & & & & & & Lower & Upper \\
\hline \multirow[t]{2}{*}{$\begin{array}{l}\text { Awaren } \\
\text { ess Rate }\end{array}$} & $\begin{array}{l}\text { Equal } \\
\text { variances } \\
\text { assumed }\end{array}$ & .465 & .496 & 2.040 & .043 & .3052 & .1497 & .0095 & .6010 \\
\hline & $\begin{array}{l}\text { Equal } \\
\text { variances } \\
\text { not } \\
\text { assumed }\end{array}$ & & & 2.006 & .047 & .3052 & .1521 & .0043 & .6062 \\
\hline
\end{tabular}


Independent T-test was used to validate the hypothesis. Calculated Significance value .496 is more than .05 , thus the $\mathrm{H} 1$ is accepted i.e. Awareness level and gender does not have any significant difference.

\section{Awareness level and different age groups}

"H2: There is no significant difference between Awareness level and different age group"

\begin{tabular}{|l|c|c|c|c|}
\hline & Sum of Squares & Mean Square & F & Sig. \\
\hline Between Groups & .204 & .102 & .119 & .888 \\
\hline Within Groups & 126.489 & .860 & & \\
\hline Total & 126.693 & & & \\
\hline
\end{tabular}

One Way Anova was used to validate the hypothesis. Calculated Significance value .888 is more than .05 , thus the $\mathrm{H} 2$ is accepted i.e. Awareness level and different age groups does not have any significant difference.

\section{Awareness level and Education level}

"H3: There is no significant difference between Awareness level and Education level"

\begin{tabular}{|l|c|c|c|c|}
\hline & Sum of Squares & Mean Square & F & Sig. \\
\hline Between Groups & 10.397 & 3.466 & 4.351 & .006 \\
\hline Within Groups & 116.297 & .797 & & \\
\hline Total & 126.693 & & & \\
\hline
\end{tabular}

In this case, a significant difference can be seen. Hypothesis testing was performed using One Way Anova. The calculated Significance value of 0.006 is less than .05 , thus the $\mathrm{H} 3$ cannot be accepted i.e. Awareness level and different age groups do have a significant difference.

\section{Awareness level and Income}

"H4: There is no significant difference between Awareness level and Income"

\begin{tabular}{|l|c|c|c|c|}
\hline & Sum of Squares & Mean Square & F & Sig. \\
\hline Between Groups & 9.265 & 4.633 & 5.799 & .004 \\
\hline Within Groups & 117.428 & .799 & & \\
\hline Total & 126.693 & & & \\
\hline
\end{tabular}

Here in the case of Awareness Level and Income, the significant value tends to be lower than p-value i.e $0.04<0.05$ therefore $\mathrm{H} 4$ cannot be accepted stating the significant difference between Awareness Level and Income Level.

\section{Awareness level and type of account}

"H5: There is no significant difference between Awareness level and type of account"

\begin{tabular}{|l|c|c|c|c|}
\hline & Sum of Squares & Mean Square & F & Sig. \\
\hline Between Groups & .920 & .920 & 1.083 & .300 \\
\hline Within Groups & 125.773 & .850 & & \\
\hline Total & 126.693 & & & \\
\hline
\end{tabular}


The null hypothesis is accepted because the sig value is greater than 0.05 . Therefore, it can be concluded that there is no significant difference between Awareness level and type of account.

\section{Awareness level and association with bank}

"H6: There is no significant difference between Awareness level and association with the bank".

\begin{tabular}{|l|c|c|c|c|}
\hline & Sum of Squares & Mean Square & F & Sig. \\
\hline Between Groups & 5.652 & 1.884 & 2.272 & .083 \\
\hline Within Groups & 121.042 & .829 & &. \\
\hline Total & 126.693 & & & \\
\hline
\end{tabular}

One Way Anova shows that $\mathrm{H} 6$ can be accepted is since the significance value is greater than 0.05 . Therefore, it is implied that there is no significant difference exists between Awareness level and association with the bank.

\section{Awareness level and frequency of using E-banking services}

"H7: There is no significant difference between Awareness level and frequency of using E-banking services."

\begin{tabular}{|c|c|c|c|c|}
\hline & Sum of Squares & Mean Square & F & Sig. \\
\hline Between Groups & 7.509 & 1.877 & 2.284 & .063 \\
\hline Within Groups & 119.185 & .822 & & $\cdot$ \\
\hline Total & 126.693 & & & \\
\hline
\end{tabular}

The results shown in the table represent that $\mathrm{H} 7$ is accepted since 0.63 (Sig. Value) > 0.05 (p-value). Therefore; there is no significant difference between Awareness level and frequency of using E-banking services.

\section{CONCLUSION \& FUTURE SCOPE}

The study revealed the factors that contributed to the awareness level of individuals towards E-banking, based on 10 statements drawn from the literature review. "Exploratory Factor Analysis" was used for the analysis of statements and extracting the factors. The implementation of exploratory factor analyses on 10 items revealed that there were 2 major factors, i.e., security mechanisms and banking updates (SMBU) and ease and quality of work-life (EQWL), which show the awareness level of customers towards E-banking services. While conducting the study, it was found that only income and educational level are the two demographic variables that show significant differences in consumer awareness level towards E-banking. Other demographic characteristics like age, gender, association with the bank, type of account, and frequency of use of services show no significant difference to the awareness level of customers. The most preferred E-banking services are ATMs and credit and debit cards. The study can be further extended to other geographical regions with greater sample sizes. Moreover, other factors with the help of a wide number of variables were also explored and established.

\section{REFERENCES}

Amutha, D. (2016). A study of consumer awareness towards e-banking. International journal of economics and management sciences, 5(4), 350353.

Anithamary,C; \& Harini, M. (2017). A study on consumer awareness and usage of E-Banking 
services with reference to Coimbatore City. International Journal of Commerce and Management Research, 3(3), 109-110.

Amsaveni, T; \& Kanagarathinam, M. (2017). A Study On Consumer Awareness Of E-Banking Services In Public Sector Banks In Coimbatore District. International Journal of Advance Research and Innovative Ideas in Education, 3(2),908-915

Al-Smadi, M. O. (2012). Factors affecting adoption of electronic banking: An analysis of the perspectives of banks' customers. International Journal of Business and Social Science, 3(17),294304

Driga, I; ISAC, C.(2014) E-BANKING SERVICES FEATURES, CHALLENGES AND BENEFITS . Annals of the University of Petroani, Economics, 14(1), 2014, 49-58

Datta, S. K. (2010). Acceptance of E-banking among Adult Customers: An Empirical Investigation in India. Journal of Internet Banking and Commerce, 15(2).

Elavarasi, M. R., \& Surulivel, S. T.(2014) Customer Awareness and Preference towards E-Banking Services of Banks (A Study of SBI). International Research Journal of Business and Management,4,59-67

ESTHER KRUPA, M; Rajasekaran, R.(2015).A Study on Customer Awareness Towards E-Banking Services in Coimbatore City. Indian Journal of Research, 4(9),230-233

Garín-Muñoz, T., López, R., Pérez-Amaral, T., Herguera, I., \& Valarezo, A. (2019). Models for individual adoption of eCommerce, eBanking and eGovernment in Spain. Telecommunications policy, 43(1), 100-111.

Kumar, V. (2018). An Empirical Study of Customers' Awareness towards Value Added Services at Banks. Marketing, 3(6),22-34

Kaur, K., \& et al;. (2016). A Study on Awareness, Utilization and Barriers towards E-Banking in East Delhi, India. International Journal of Innovative Studies in Sociology and Humanities (IJISSH), 1(1),44-52

Khatri, J; \& Upadhyaya-Dhungel, K. (2013). Internet banking in Nepal: Use and challenges. Banking
Journal, 3(2), 57-77.

Nustini, Y., \& Fadhillah, N. (2020). Factors that Influence the Use of e-Banking and the Effect on Consumptivism. Review of Integrative Business and Economics Research, 9, 330-345.

Nagaraj, R; \& Jegatheeswari, P. (2016). A Study on the Customer Awareness of E- Banking Services in Madurai City. International Journal of Scientific Development and Research,1(8),219234

Roscoe, J.T. (1975), Fundamental Research Statistics for the Behavioural Sciences, 2nd ed., Holt Rinehart \& Winston, New York, NY.

Sekaran, U. (2003), Research Methods for Business A Skill Building Approach, 4th ed., Wiley and Sons, New York, NY. 